\title{
Isolation and Purification of Alfa Grass Kraft Lignin from Industrial Waste
}

\author{
Mohamed Ammar*, Nabawia Mechi, Hela Slimi and Elimame Elaloui \\ Materials, Environment and Energy Laboratory, University Gafsa, Tunisia
}

Submission: May 05, 2017; Published: July 27, 2017

*Corresponding author: Mohamed Ammar, Materials, Environment and Energy Laboratory, University Gafsa, Tunisia, Email: ammarmohamed10@ yahoo.fr

Abstract

Kraft lignins (KL) were obtained from pulping alfa grass (Stipa Tenacissima) by increasing black liquor $\mathrm{pH}$ using sulfuric acid at four different values $(6,4.5,2.5$ and 1.5$)$. The obtained lignin was treated with acetosolv process and carefully characterized by different spectroscopic and analytical methods, namely: FTIR, UV and NMR spectroscopy.

These techniques showed that KL is composed of p-hydroxyphenyl-guaiacyl-syringyl (HGS) sequences. The amount of lignin decreases when the $\mathrm{pH}$ increases. The thermal stability of lignin was studied by TGA and the results show that carbohydrate linkages at pH 6 were further cleaved compared to $\mathrm{pH} 1.5$ which increasing the sample purity.

Keywords: Kraft lignin; HGS sequences; Lignin purity; Thermal stability

\section{Introduction}

Alfa grass (Stipa Tenacissima) is widely available lignocellulosic biomass in Tunisia, which occupied more than 380 thousand hectares in different regions (Kasserine, Sidi Bouzid, Gafsa and Kairouan) [1,2]. This annual plant is an important source for pulping industry in Tunisia, because this biomass contains about $70 \%$ of holocellulose and $25 \%$ of lignin, which justified the delignification. Moreover, holocellulose is easy to be isolated using soda process $\left(13\right.$ minutes at $\left.160^{\circ} \mathrm{C}\right)$. As in most cases, after pulping the dissolved lignin (black liquor) is burned for energy recovery purpose. The black liquor contains a wide variety of compounds (chemicals and derived from lignin).

Lignin is a phenolic, three-dimensional, bio-polymer occurring in plant tissues, and whose role is reinforcing cellulose fibers. It is based on three phenyl-propanoid unit, connected with each other's through ether and ester linkages [3-5], thus resulting in a complex macromolecular structure. Yet, many studies have been made in the past for finding new ways of lignin valorization. For instance, it has been proved that glyoxalated lignin can be an effective precursor of adhesive resin for formaldehyde free particleboards [6-8]. Conventinally, the kraft lignin has been recovered from black liquor, in laboratory or industrial plants, by precipitation with mineral acids like sulphuric or hydrochloric acids. Organosolv lignins are being examined because they show significantly better solubility and thermal properties than kraft lignins, but the yield of extraction is very low [9]. Organosov lignin produced by the organosolv method is a superior reagent feedstock compared to kraft lignin produced in kraft pulping, due to the absence of sulphur and an increased fraction of aromatics un-substituted in the reactive ortho-position required for chemical fonctionalisation. One of the disadvantages of Kraft lignins is that they generally tend to have weaker purity and reactivity $[10,11]$. In this study the main focus on the method of lignin purification to obtain material with higher purity. Selective precipitation was achieved by decreasing the $\mathrm{pH}$ of the black liquor and the purity of the resulting fraction was carried out by UV spectroscopy and TGA.

\section{Experimental}

The black liquor use for obtaining lignin was kindly supplied by SNCPA -National Company of Cellulose and Alfa Pulping (Kasserine, Tunisia), the lignin was precipitated by decreasing black liquor pH from 12.5-6, 4.5, 2.5 and 1.5 and by adding sulfuric acid.

To reduce carbohydrate content, lignin $(10 \mathrm{~g})$ was treated by acetic acid $(90 \%)$ containing $0.1 \%$ hydrochloric acid. The reaction is conducted under atmospheric pressure at $80{ }^{\circ} \mathrm{C}$ during 5 hours. The obtained products as well as the initial lignin were characterized by spectroscopic methods. 
The acquisition of [12] C-NMR spectra was recorded at 25 ${ }^{\circ} \mathrm{C}$ in DMSO-d6 on a Bruker DMX-300FT-NMR spectrometer at a frequency of $300 \mathrm{MHz}$. Whereas the FTIR spectra were performed using a Bio-Rad spectrophotometer with a resolution of $4 \mathrm{~cm}^{-1}$ and scanning a wave length range from 500 to $4000 \mathrm{~cm}^{-1} . \mathrm{KBr}-$ based solid pellets made of a suspension of $1 \mathrm{mg}$ of the material under investigation and $100 \mathrm{mg}$ of anhydrous $\mathrm{KBr}$.

The UV spectra of the various lignins were recorded on an ultraviolet/visible spectrophotometer (Shimadzu double-beam spectrophotometer UV 1800). The different fraction lignin sample $(5 \mathrm{mg})$ was dissolved in $95 \%(\mathrm{v} / \mathrm{v})$ dioxane aqueous solution $(10 \mathrm{~mL})$. About $1 \mathrm{~mL}$ aliquot was diluted to $10 \mathrm{~mL}$ with $50 \%(\mathrm{v} / \mathrm{v})$ dioxane aqueous solution and the absorbance between 250 and $400 \mathrm{~nm}$ was recorded and measured. The measurement test was done at least five times. Lignin was dissolved in THF $(1 \mathrm{mg} / \mathrm{mL})$ for GPC study with an Agilent 1200 series liquid chromatography equipping a differential refractive index detector. Polystyrene standards were used to make calibration.

For thermal gravimetric analysis (TGA, Perkin-Elmer Pyris 1 TGA-7), about $8 \mathrm{mg}$ of lignin was put into a platinum sample pan and heated from 50 to $800{ }^{\circ} \mathrm{C}$ at a heating rate of $10{ }^{\circ} \mathrm{C} /$ min under a nitrogen atmosphere with a flow rate of $20 \mathrm{ml} / \mathrm{min}$. Curves of weight loss and derivative weight loss (DTG) were plotted.

\section{Results and Discussion}

Figure 1 shows the variation of the amount of lignin depending on $\mathrm{pH}$ insulation, we note that the amount of lignin recovered decreases when the $\mathrm{pH}$ increases. Specifically the precipitate regarding total dissolved solids $(10 \mathrm{~g})$, increasing from $1.5 \mathrm{~g}$ to $7 \mathrm{~g}$ when the $\mathrm{pH}$ was lowered from 6 to 1.5 .

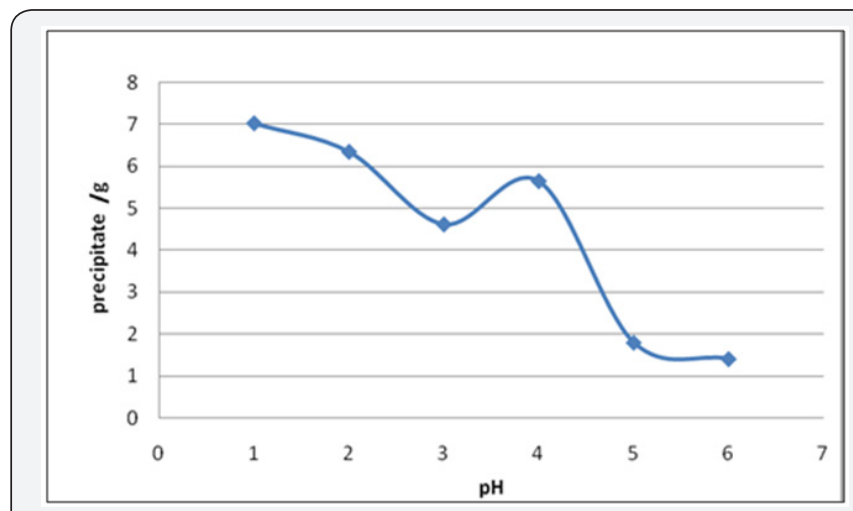

Figure 1: Variation of lignin yield depending on $\mathrm{pH}$.

FTIR spectra of different samples are presented in Figure 2 The peak at $668 \mathrm{~cm}^{-1}$ corresponds to carbohydrates, we note that the amount of carbohydrates is higher for low $\mathrm{pH} 1.5$, thus isolating lignin is purer for $\mathrm{pH}$ values between 4.5 and 6 , but the mass yield is low [12]. For pH 2.5 and 1.5 the mass yield is high but the amount of carbohydrate is very high.

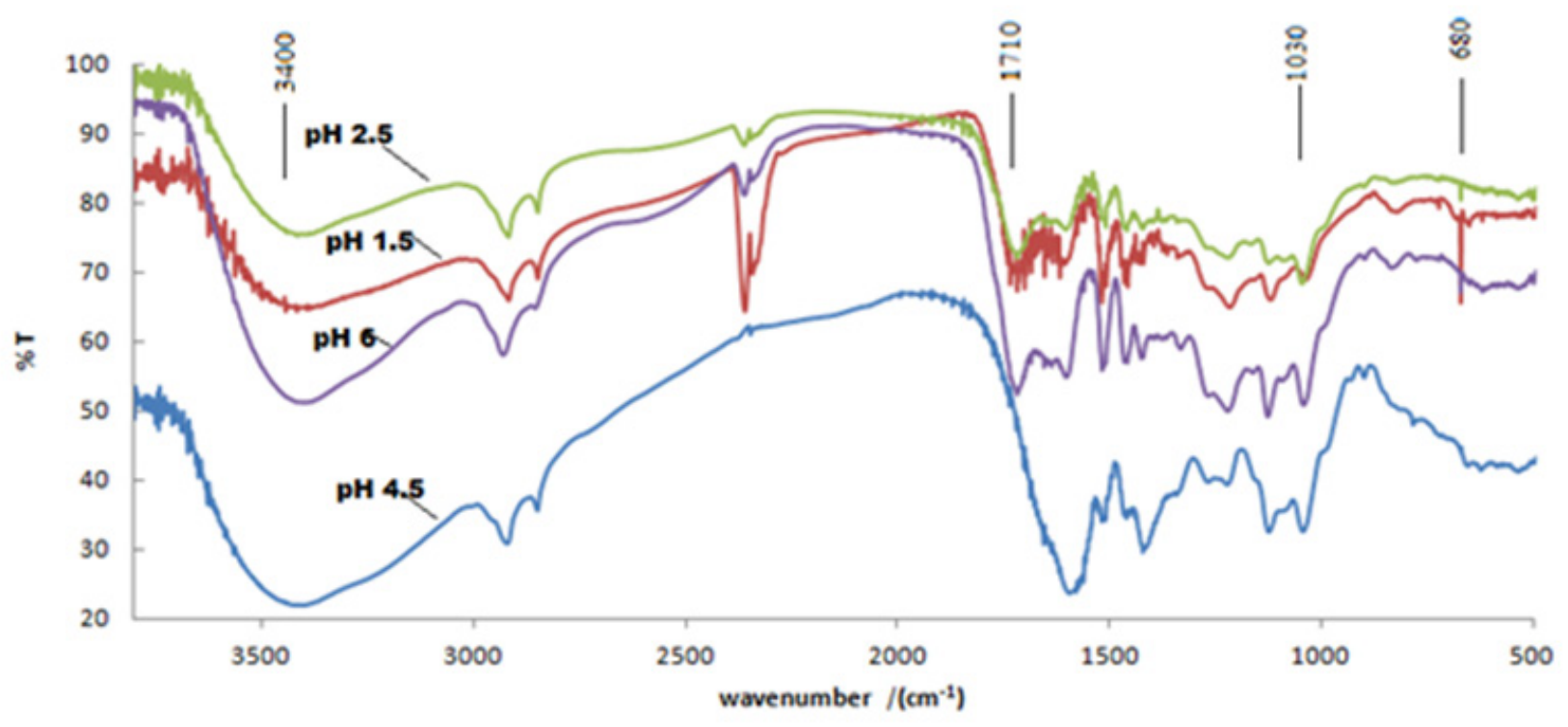

Figure 2: FTIR spectra of different lignin fraction.

The vibration of $\mathrm{C}=0$ bond appears in $1710 \mathrm{~cm}^{-1}$, it can be seen that this peak is more intense for low $\mathrm{pH}$ values which explains the degradation of color float fun to yellow as the chromophores become less soluble in the $\mathrm{pH} 2.5$ and 1.5 (Figure 3). 


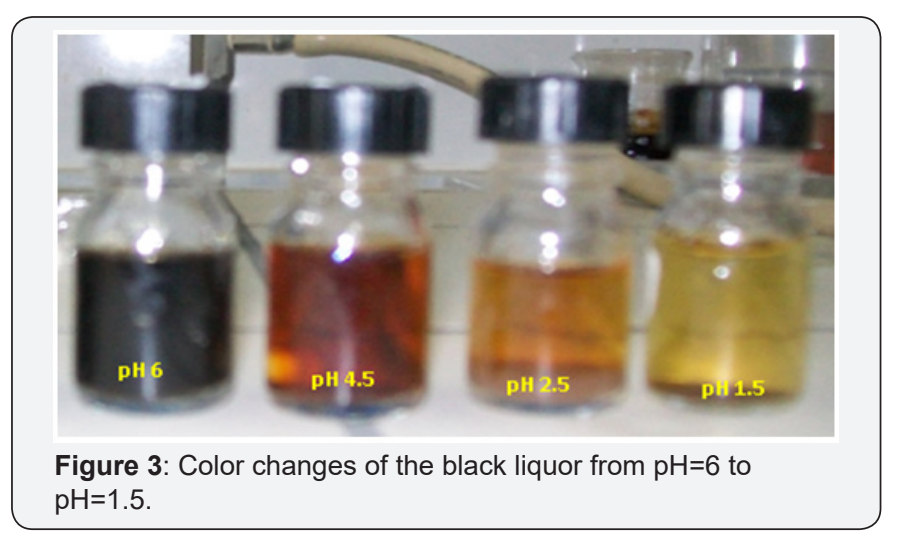

The infrared spectrum of all samples has a first series of bands common to many phenolic structures: $3605-3150 \mathrm{~cm}^{-1}(\mathrm{OH}$ elongation in functions alcohols and phenols), $3000-2800 \mathrm{~cm}^{-1}$ (C-H stretching of aliphatic and aromatic methyl and methylene groups), 630-1580 $\mathrm{cm}^{-1}$ aromatic skeleton, $1505-1480 \mathrm{C}-\mathrm{H},-\mathrm{CH}_{2}$ and $-\mathrm{CH}_{3}$ groups $[12,15]$.

[12] C-NMR spectrum of isolated lignin at pH 6 and 1.5 was established and the results as shown in Figure 4 The syringyl (S) units were identified with signals at $152.4 \mathrm{ppm}$ (C-3 /C5: S), 147.9ppm (C-3/C-5: S no etherified), 137.3ppm (C-4: S etherified), 134.6ppm (C-1: S etherified 134.3ppm), 131.2ppm (C-1: $\mathrm{S}$ no etherified) [16].

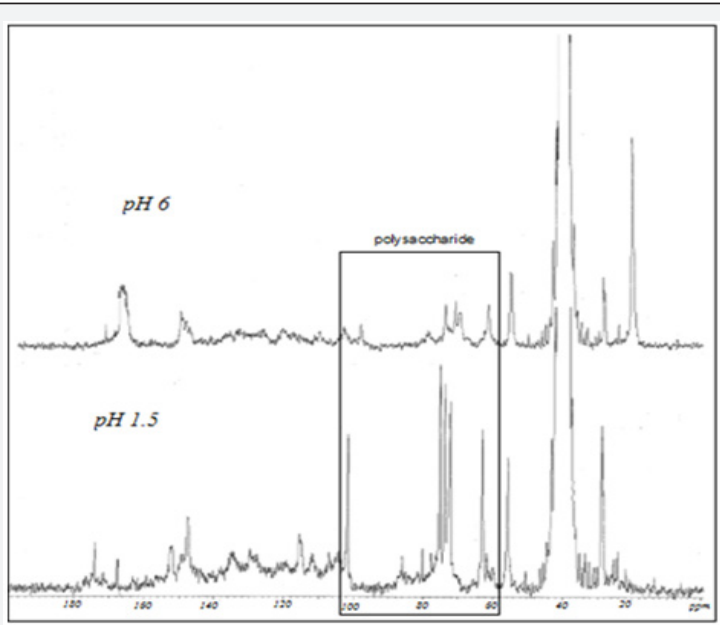

Figure 4: NMR spectra of lignin isolated at $\mathrm{pH} 1.5$ and $\mathrm{pH} 6$.

Guaiacyl (G) units gave signals at en147.5ppm(C-4 G), 134.3 (C-1 G etherified) and 115ppm (C-5 G), 149.4ppm (C-3 G). The p-hydroxyphenyl $(\mathrm{H})$ units appeared as a weak signal at $120 \mathrm{ppm}$ (C-2/C-6, H). These signals confirmed that lignin fraction could be justified as HGS-lignin $[17,18]$.

From the [12] C-NMR spectrum, it can be remark that the most striking characteristic is the close to absence of typical polysaccharide signals which can be appears between 57 and $103 \mathrm{ppm}$ in the spectra of $\mathrm{pH} 6$. This result confirms that lignin isolated at $\mathrm{pH}=6.5$ is the purer sample.
UV spectroscopy has been used to semi-quantitatively determine the purity of lignin or monitor the lignin distribution among various tissues of gymnosperm and dicotyledonous angiosperm with respect to the concentration. In this study, UVvis absorption measurements of the four lignin fractions were carried out with a dioxane/water mixture, which solubilized the lignin but was limited to wavelengths above $250 \mathrm{~nm}$. Figure 5 illustrates the UV-vis spectra of the lignin fractions isolated at $\mathrm{pH}: 6,4.5,2.5$ and 1.5. Obviously, the spectra of the four lignin fractions are similar except for the magnitude of the absorption coefficient representations. The maximum absorbance $\lambda$ at $280 \mathrm{~nm}$ originated from non-conjugated phenolic hydroxyl groups in the lignin. The presence of the second characteristic region of lignin absorption around $\lambda$ of $318 \mathrm{~nm}$ could be assigned to the presence of both ferulic acids and p-coumaric acids [19]. As shown in Figure 5, the highest absorption coefficient occurred in Lignin $\mathrm{pH} 6$ preparations, suggesting that the most pure lignin preparation could be obtained when the $\mathrm{pH}$ was decreased at 6 .

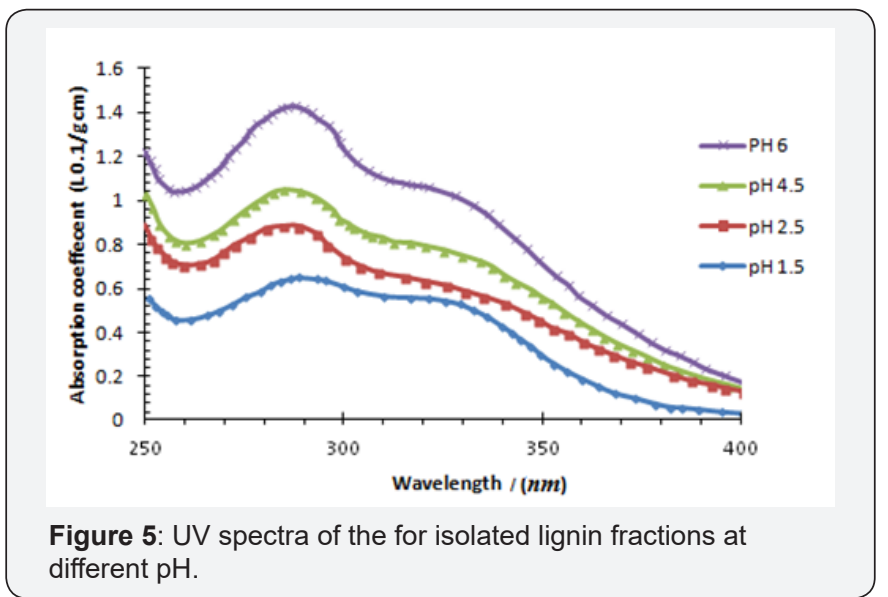

On the other hand, the lowest absorption coefficients of Lignin pH 1.5 fractions (Figure 5), released during the treatment at $\mathrm{pH}=1.5$, were probably due to a high amount of associated hemicelluloses and other non-lignin materials, such as ash and inorganic salt. Moreover, the shift of the maximum wavelength from $280 \mathrm{~nm}$ to $276 \mathrm{~nm}$ implied that a higher content of syringyl (S) units in lignin fraction (Lignin $\mathrm{pH}$ 6) since S units exhibit the bands at somewhat shorter wavelengths, specifically at 268$277 \mathrm{~nm}$.

From (Table 1), the Mw and Mn of Lignin $\mathrm{pH}$ 6, Lignin $\mathrm{pH} 4.5$, and Lignin $\mathrm{pH} 1.5$ were both gradually decreasing.

Table 1: Molecular Weights of lignin isolated at pH 6, 4.5 and 1.5.

\begin{tabular}{|c|c|c|c|}
\hline Samples & Mw (g/mol) & Mn (g/mol) & Mw/Mn \\
\hline Lignin 6 & 24622 & 15656 & 1.57 \\
\hline Lignin 4.5 & 22796 & 14445 & 1.58 \\
\hline Lignin 1.5 & 19447 & 12500 & 1.56 \\
\hline
\end{tabular}

The cross-linking degree of Lignin pH 6 among the three fractions was becoming larger and that lignin with larger molecular weight would be precipitated earlier in the higher $\mathrm{pH}$ 
value. That is because lignin macromolecule is fully dissolved in the form of lignin sodium salt and hydrophilic colloid in the black liquor. When the black liquor is neutralized with the acid and its $\mathrm{pH}$ value is gradually decreased, the electronic substitution reaction occurs and the alkali lignin colloid is damaged at the same time, which results in generating insoluble lignin $[20,21]$. Then lignin with larger molecular weight may possess more complex spatial structure and worse hydrophilicity, which leads to its precipitation at a relative higher $\mathrm{pH}$ value.

Figure $6 \mathrm{a} \& 6 \mathrm{~b}$ shows the thermogravimetry (TG) curves, where the weight loss of lignins is plotted in relation to the temperature of thermal degradation (Figure 6a), and the first derivatives of this curve (weight loss rate) is known as differential thermogravimetry (DTG) (Figure 6b). Three stages of decomposition can be clearly identified in the TG curves for the two lignins. In the first stage, temperature below $200{ }^{\circ} \mathrm{C}$, the weight loss of the two materials were less than $7 \%$ and corresponds to the evaporation of light volatiles (mainly water).
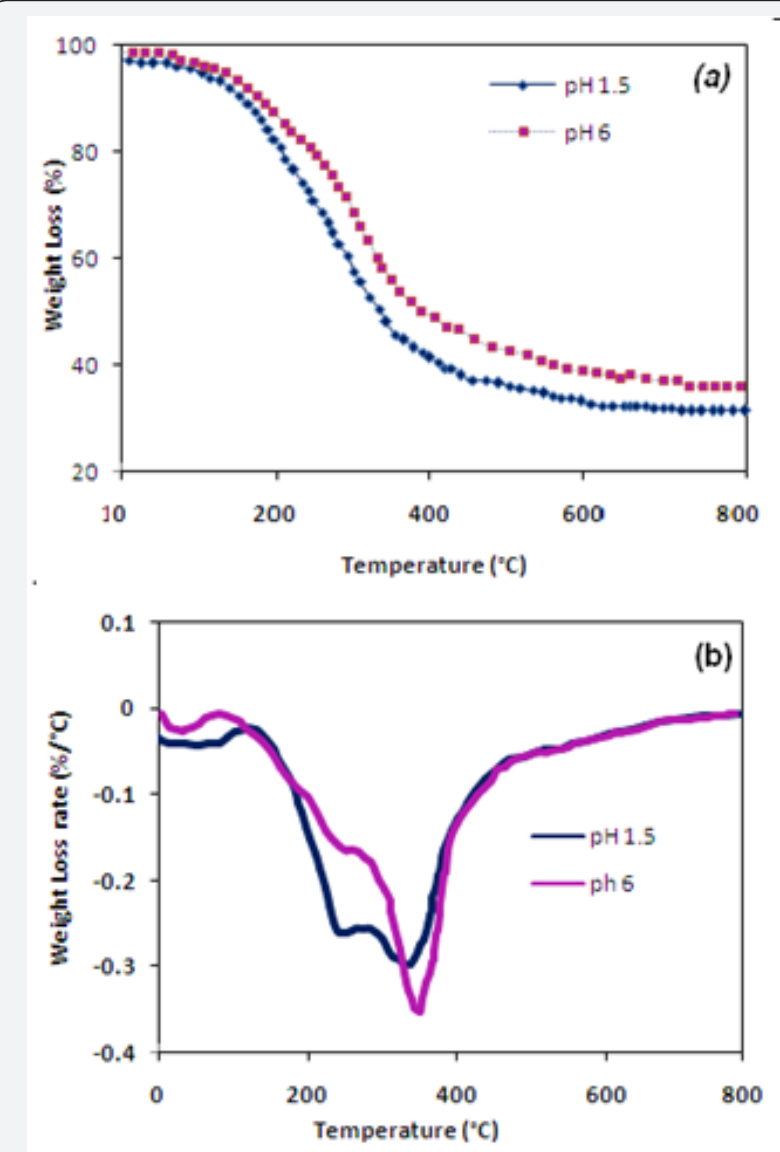

Figure 6: ATG (a) and DTG (b) curves of lignin isolated at pH 6 and $\mathrm{pH} 1.5$.

The second stage of decomposition, occurring between 200 and $500{ }^{\circ} \mathrm{C}$, corresponds to a remarkable drop in weight of samples (38-48\%) due to liberation of volatile hydrocarbon from rapid thermal decomposition of hemicelluloses, cellulose and some part of lignin. The third stage, after $500{ }^{\circ} \mathrm{C}$, the weight loss is less important than the second period due to the steady decomposition of the more heavy components mainly from lignin $[22,23]$.

The isolated lignin exhibited different DTG profiles. The first peak for the two lignins ranged from 40 to $125{ }^{\circ} \mathrm{C}$ and corresponded to the gradual evaporation of the moisture. For Lignin pH 6 a second large peak could be observed from approximately $125-700{ }^{\circ} \mathrm{C}$, with a shoulder at $293^{\circ} \mathrm{C}$. Lignin $\mathrm{pH}$ 1.5 showed a similar profile but with a great weight loss rate around $293{ }^{\circ} \mathrm{C}$. According to Caroline [12], hemicellulose is the most reactive compound which decomposes at between 200 and $350{ }^{\circ} \mathrm{C}$. Lignin is more thermally stable and decomposes between 250 and $500{ }^{\circ} \mathrm{C}$ [23-26]. Lignin pH 1.5 presented more important peaks in the region of the hemicelluloses confirming the UV analysis. Carbohydrate linkages in pH 6 were further cleaved compared to $\mathrm{pH} 1.5$ which increasing the sample purity.

\section{Conclusion}

Lignin separation and purification was achieved by selective precipitation. While decreasing $\mathrm{pH}$ from 6 to 1.5 the amount of precipitate increase and black liquor color attenuated.

The NMR spectra confirmed that lignin fraction could be justified as HGS-lignin and lignin isolated at $\mathrm{pH} 6$ is the purer sample. According to the TGA analysis, Carbohydrate linkages in $\mathrm{pH} 6$ were further cleaved compared to $\mathrm{pH} 1.5$ which increasing the sample purity.

\section{Acknowledgement}

We greatly acknowledge financial support of the ministry of Higher Education and Scientific Research of Tunisia (Ministere de l Enseignement Superieur ET de la Recherche Scientifique de Tunisie). The authors are grateful express their sincere gratitude to the "PHC-UTIQUE CMCU" for their financial supports and professor Mohamed naceur belgacem (Laboratoire de Génie des Procédés Papetiers (LGP2), UMR CNRS 5518, Grenoble France).

\section{References}

1. Belgacem MN, Candini A (2008) Monomers, Polymers and Composites from renewable Resources. Elsevier.

2. Belgacem MN, Blayo A, Gandini A (2003) Organosolv lignin as filler in inks, varnishes and paints. Ind Crops Prod 18(2): 145-153.

3. Mansouri N-E E, Salvadó J (2006) Structural characterization of technical lignins for the production of adhesives: application to lignosulfonate, kraft, soda-anthraquinone, organosolv and ethanol process lignins. Ind Crops Prod 24: 8-16.

4. Tejado A, Pena C, Labidi J, Echeverria JM, Mondragon I (2007) Physicochemical characterization of lignins from different sources for use in phenol-formaldehyde resin synthesis. Bioresour Technol 98(8): 16551663.

5. Faix O (1992) Fourier transforms infrared spectroscopy. In: Lin SY, Dence CW (Eds.), Methods in lignin chemistry. Springer-Verlag, Berlin, pp. 83-109. 
6. Elaine C, Ramires D, Megiatto, Christian G, Alain C, et al. (2010) Valorization of an Industrial Organosolv-Sugarcane Bagasse Lignin: Characterization and Use as a Matrix in Biobased Composites Reinforced With Sisal Fibers. Biotechnol Bioeng 107(4): 612-621.

7. Yasuyuki M (2015) Conversion of technical lignins to functional materials with retained polymeric properties. J Wood Sci 61(3): 230250.

8. Yasumitsu U, Keiichi K (2015) Utilization of wood cell wall components. J Wood Sci 61(5): 447-454.

9. Sellers T, Lora J, Okuma M (1994) Organosolv-lignin-modified phenolics as strandboard binder 1 organosolv lignin and modified phenolic resin. Mokuzai Gakkaishi 40: 1073-1078.

10. Berg A, Janssen W, Ballé S, Kunz RG, Klein W (1995) Delignification of cellulosic raw material using acetic acid, nitric acid and ozone.

11. Bikova T, Treimanis A (2004) UV-absorbance of oxidized xylan and monocarboxyl cellulose in alkaline solutions. Carboh Polym 55(3): 315-322.

12. Caroline V, Aurore R, Nicolas J, Christophe B, Michel P (2011) Impact of formic/acetic acid and ammonia pre-treatments on chemical structure and physico-chemical properties of Miscanthus x giganteus lignins. Polym Degr Stab 96(10): 1761-1770.

13. Cateto C, Filomena B, Naceur B, Alirio R (2009) Polyuréthanes à base de lignines: synthèse, caractérisation et applications, these Institut Polytechnique de Grenoble 1: 230.

14. Ali A, Alinaghi K, Ahmad M, Yahya H, Nathalie M, et al (2010) Isolation and Chemical Structure Characterization of Enzymatic Lignin from Populus deltoids. Wood J Appl Polym Sci 118(1): 469-479.

15. Satoru T, Hikaru K (2015) A review of recent application of near infrared spectroscopy to wood science and technology. J Wood Sci 61(3): 213-220.

16. Gosselink RJA, Jong E, Guran B, Abächerli A (2004) Co-ordination network for lignin-standardisation, production and applications adapted to market requirements (EUROLIGNIN). Ind Crops Prod 20(2): 121-129.
17.Xiao B, Sun XF, Sun R (2001) Chemical, structural and thermal characterizations of alkali-soluble lignins, hemicelluloses and cellulose from maize stems, rye straw and rice straw. Polym Degr Stab 74: 307319.

18. Brosse N, Sannigrahi P, Ragauskas A (2009) Pretreatment of Miscanthus $\mathrm{x}$ giganteus using the ethanol organosolv process for ethanol production. Ind Engin Chem Res 48(18): 8328-8334.

19. Yasuyuki M, Toyoki I, Yasuo TTH, Kazuhiko F (2011) Conversion of sulfuric acid lignin generated during bioethanol production from lignocellulosic materials into polyesters with $\boldsymbol{\varepsilon}$-caprolactone. J Wood Sci 57(3): 214-218.

20.Xiao-hong L, Shu-bin W (2014) Chemical Structure and Pyrolysis Characteristics of the Soda-Alkali Lignin Fractions. BioRes 9(4): 62776289.

21. Tainise VL, Fabricio AH, Thiago AS, Luiz PR, Graciela IBM, et al. (2015) Hardwood and softwood kraft lignins fractionation by simple sequential acid precipitation. Separ Purif Techn 154: 82-88.

22. Kelly R, Giuseppe M (2010) Characteristics of Lignin from Flax Shives as Affected by Extraction Conditions. Int J Molec Sci 11(10): 40354050 .

23. Chan MK, Ye, Png ZM, Zeng ZM, Wang X, et al. (2016) Valorization of Lignin: Effective Conversion of Depolymerized Lignin to Oil by Simple Chemical Modifications. Waste Biomass Valor 1-8.

24. Abatzoglou N, Chornet E, Belkacemi K, Overend RP (1992) Phenomenological kinetics of complex systems: the development of a generalized severity parameter and its application to lignocellulosics fractionation. Chem Enging Sci 47(5): 1109-1122.

25. Araceli G, Ana T, Maria A, Jalel L (2010) Study of the antioxidant capacity of Miscanthus sinensis lignins. Process Biochem 45(6): 935940 .

26. Benjelloun-Mlayah B, Delmas M, Avignon G (2006) Installation for implementing a method for producing paper pulp, lignins and sugars and production method using such an installation.

\section{Your next submission with Juniper Publishers} will reach you the below assets

- Quality Editorial service

- Swift Peer Review

- Reprints availability

- E-prints Service

- Manuscript Podcast for convenient understanding

- Global attainment for your research

- Manuscript accessibility in different formats

( Pdf, E-pub, Full Text, Audio)

- Unceasing customer service

Track the below URL for one-step submission https://juniperpublishers.com/online-submission.php 